\title{
Histomorphometry and uterine proteomics during the normal reproductive cycle in bitches
}

\author{
Histomorfometria e proteômica uterina durante o ciclo reprodutivo normal em cadelas \\ Histomorfometría y proteómica uterina durante el ciclo reproductivo normal en perras
}

Received: 08/04/2021 | Reviewed: 08/13/2021 | Accept: 08/18/2021 | Published: 08/22/2021

\author{
Luana Azevedo de Freitas \\ ORCID: https://orcid.org/0000-0002-1851-2851 \\ Universidade Estadual do Ceará, Brazil \\ E-mail: lualaf@ hotmail.com \\ Fábio Roger Vasconcelos \\ ORCID: https://orcid.org/0000-0001-6080-6370 \\ Universidade Federal do Ceará, Brazil \\ E-mail: fr.vasconcelos@yahoo.com.br \\ Arlindo Alencar Araripe Noronha Moura \\ ORCID: https://orcid.org/0000-0002-8271-5733 \\ Universidade Federal do Ceará, Brazil \\ E-mail: arlindo.moura@gmail.com \\ Stefanie Bressan Waller \\ ORCID: https://orcid.org/0000-0001-6719-1794 \\ Universidade Federal de Pelotas, Brazil \\ E-mail: waller.stefanie@yahoo.com.br \\ Paula Priscila Correia Costa \\ ORCID: https://orcid.org/0000-0001-6421-0689 \\ Universidade Federal de Pelotas, Brazil \\ E-mail: paulapriscilamv@yahoo.com.br \\ Brenda Madruga Rosa \\ ORCID: https://orcid.org/0000-0003-4087-0054 \\ Universidade Federal de Pelotas, Brazil \\ E-mail: breenda.rosa@hotmail.com \\ Wesley Lyeverton Correia Ribeiro \\ ORCID: https://orcid.org/0000-0002-2784-0013 \\ Universidade Federal do Ceará, Brazil \\ E-mail: wesleylyeverton@yahoo.com.br \\ Lúcia Daniel Machado da Silva \\ ORCID: https://orcid.org/0000-0001-9793-1968 \\ Universidade Estadual do Ceará, Brazil \\ E-mail: lucia.daniel.machado@hotmail.com
}

\begin{abstract}
We aimed to evaluate the histomorphometry and proteomic profile of the canine uterus during all stages of the reproductive cycle. Eighteen healthy female dogs had their estrous cycle identified by clinical evaluation, vaginal cytology, and serum progesterone levels, which were allocated to the proestrus $(n=5)$, estrus $(n=5)$, diestrus $(n=5)$, and anestrus $(n=3)$ groups. All were submitted to elective ovariosalpingohysterectomy, and the uteri were collected for histomorphometric measurement (Image $\mathbf{J}$ software). For proteomic analysis, fragments of the uterine horns were subjected to protein measurement (Bradford method) and extraction by 2D electrophoresis (PDquest software). The results showed that the diestrus promoted greater values of thickness in the uterine structures $(\mu \mathrm{m})$ : uterine wall $(2,223.8 \pm 229.8)$, endometrium $(819.7 \pm 109.1)$, and myometrium (1,392.6 \pm 294.2$)$. Uterus showed a protein profile with good reproducibility per phase (pI: 3.5-9.0; PM: 24-150 KDa), with 11 spots in all phases. Despite the greatest histomorphometric changes in the diestrus, we observed a greater number of spots in the estrus (253 \pm 45$)$, followed by the proestrus (185 \pm 21$)$, diestrus $(113 \pm 39)$, and anestrus $(80 \pm 21)$. This finding showed probable participation of these proteins in the uterine preparation for receiving gametes for fertilization. Our results showed greater uterine thickness in the diestrus, and greater protein secretion in the estrus, contributing to the prospection of identification of proteins responsible for the biological reproduction processes.
\end{abstract}

Keywords: Bitches; Breed; Estrous Cycle; Histology; Proteins; Proteome; Uterus. 


\begin{abstract}
Resumo
Nós objetivamos avaliar a histomorfometria e o perfil proteômico do útero canino durante todas as fases do ciclo reprodutivo. Dezoito cadelas saudáveis tiveram seu ciclo estral identificado por avaliação clínica, citologia vaginal e níveis séricos de progesterona, que foram alocados para o proestro $(n=5)$, estro $(n=5)$, diestro $(n=5)$ e anestro $(n=$ 3) grupos. Todas foram submetidas à ovariosalpingohisterectomia eletiva, e os úteros foram coletados para mensuração histomorfométrica (software Image J). Para a análise proteômica, fragmentos das trompas uterinas foram submetidos à dosagem de proteínas (método de Bradford) e extração por eletroforese 2D (software PDquest). Os resultados mostraram que o diestro promoveu maiores valores de espessura nas estruturas uterinas $(\mu \mathrm{m})$ : parede uterina $(2.223,8 \pm 229,8)$, endométrio $(819,7 \pm 109,1)$ e miométrio $(1.392,6 \pm 294,2)$. O útero apresentou um perfil proteico com boa reprodutibilidade por fase (pI: 3,5-9,0; PM: 24-150 KDa), com 11 manchas em todas as fases. Apesar das maiores alterações histomorfométricas no diestro, observamos um maior número de manchas no estro $(253 \pm 45)$, seguidas do proestro $(185 \pm 21)$, diestro $(113 \pm 39)$ e anestro $(80 \pm 21)$. Esse achado mostrou provável participação dessas proteínas no preparo uterino para recebimento de gametas para fertilização. Nossos resultados mostraram maior espessura uterina no diestro e maior secreção de proteínas no estro, contribuindo para a prospecção e identificação de proteínas responsáveis pelos processos de reprodução biológica.
\end{abstract}

Palavras-chave: Cadelas; Raça; Ciclo Estral; Histologia; Proteínas; Proteoma; Útero.

\title{
Resumen
}

Nuestro objetivo fue evaluar la histomorfometría y el perfil proteómico del útero canino durante todas las etapas del ciclo reproductivo. Se identificó el ciclo estral de dieciocho perras sanas mediante evaluación clínica, citología vaginal y niveles de progesterona sérica, que se asignaron al proestro $(n=5)$, estro $(n=5)$, diestro $(n=5)$ y anestro $(n$ = 3) grupos. Todos se sometieron a una ovariosalpingohisterectomía electiva y se recogieron los úteros para la medición histomorfométrica (software Image J). Para el análisis proteómico, los fragmentos de los cuernos uterinos se sometieron a medición de proteínas (método de Bradford) y extracción por electroforesis 2D (software PDquest). Los resultados mostraron que el diestro promovió mayores valores de espesor en las estructuras uterinas $(\mu \mathrm{m})$ : pared uterina $(2.223,8 \pm 229,8)$, endometrio $(819,7 \pm 109,1)$ y miometrio $(1.392,6 \pm 294,2)$. El útero mostró un perfil proteico con buena reproducibilidad por fase (pI: 3,5-9,0; PM: 24-150 KDa), con 11 manchas en todas las fases. A pesar de los mayores cambios histomorfométricos en el diestro, observamos un mayor número de manchas en el estro $(253 \pm 45)$, seguido del proestro $(185 \pm 21)$, diestro $(113 \pm 39)$ y anestro $(80 \pm 21)$. Este hallazgo mostró una probable participación de estas proteínas en la preparación uterina para recibir gametos para la fertilización. Nuestros resultados mostraron mayor grosor uterino en el diestro y mayor secreción de proteínas en el estro, contribuyendo a la prospección de identificación de proteínas responsables de los procesos de reproducción biológica.

Palabras clave: Perras; Raza; Ciclo Estral; Histología; Proteínas; Proteoma; Útero.

\section{Introduction}

The female reproductive organs are complete at birth, except the uterus, which differentiates into three histological structures in the postnatal period: the endometrium, myometrium, and perimeter (Holst, 2019). The bitch's uterus develops continuously from birth to 180 days of life (Ramos et al., 2015), developing until the stage of the beginning of the estrous cycle. At each estrous cycle, the uterus prepares to harbor the conceptus through the action of ovarian hormones (Holst, 2019; Vermeirsch et al., 2000), which estrogen stimulates intense mitosis of endometrial cells in the proliferative phase, and progesterone stimulates hypertrophy and hyperplasia of them in the secretory phase (Aplin et al., 2008).

Thus, substances synthesized and secreted by endometrial cells are essential for pregnancy and embryo survival (Holst, 2019), however, molecular changes in the glands and endometrial epithelium alter the composition of uterine secretions (Gao et al., 2009).

Molecular studies have identified uterine proteins in domestic females (Faulkner et al., 2013; Lee et al., 2013; Freitas et al., 2015; Swegen et al., 2017), constituting potential biotechnological applicability for the early diagnosis and treatment of reproductive disorders. However, studies of proteomic analysis in dogs are scarce, addressing pyometra (Kuleš et al., 2020), pregnancy (Valdés et al., 2019) or diestrus phases (Praderio et al., 2019), estrus (Fahiminiya et al., 2010), and proestrus (Reynaud et al., 2015), lacking studies that cover all phases of the estrous cycle.

In this way, we aimed to evaluate and measure the female uterus by histomorphometry and describe the protein profile in all phases of the estrous cycle. 


\section{Methodology}

\subsection{Research}

This work is an experimental study of a quantitative nature (Pereira et al., 2018) for the purpose of evaluating and measuring the healthy uterus and respective protein profile during the estrous cycle of bitches.

\subsection{Ethical Permission}

The study protocol and all experimental procedures were approved by the Ethics Committee in Animal Experimentation (Comitê de Ética para Uso Animal - CEUA, State University of Ceará, Fortaleza, CE, Brazil), which protocol number is $5999508 / 2015$.

\subsection{Experimental Animals and Procedures}

For the experimental study, 18 healthy and pubescent bitches, weighing between $10 \mathrm{~kg}$ and $45 \mathrm{~kg}$ (body score: 3-4), were used, and the majority of them were mongrel. All had a history of at least one previous pregnancy, were fed commercial granulated feed, and belonged to private owners. For the study, the estrous cycle was determined, followed by ovariosalpingohysterectomy (OSH) elective for later collection of samples for histomorphological and proteomic analysis.

\subsection{Determination of the Estrous Cycle and Ovariosalpingohysterectomy (OSH)}

To determine the estrous cycle, the clinical evaluation (reproductive anamnesis and estrous clinical signs), vaginal cytology (Holst et al., 2019), and hormonal confirmation by serum progesterone measurement (ELFA - Enzyme-Linked Fluorescent Assay; MiniVidas, bioMérieux) technique were performed. Thus, the animals were divided into the following groups: proestrus ( $n=5)$, estrus ( $n=5)$, diestrus $(n=5)$, and anestrus $(n=3)$.

Ovariosalpingohysterectomy (OSH) was performed in a surgical environment at the Laboratory of Carnivore Reproduction (Universidade Estadual do Ceará) after 12-hours of hydric and food fasting. The bitches were induced to general anesthesia with acepromazine $(0.1 \mathrm{mg} / \mathrm{kg}$, intramuscularly, Acepran $0,2 \%$, Vetnil, Louveira, SP, Brazil) and propofol $(5.0 \mathrm{mg} / \mathrm{kg}$, intravenous, Propovan, Cristália, São Paulo, SP, Brazil), and were maintained by inhalation anesthesia with isoflurane (Forane, Baxter, USA).

\subsection{Histomorphometric Analysis}

For histomorphometric analysis, the collected uteri were washed with distilled water to remove excess adipose tissue and dissected to obtain fragments of uterine horns $(0.5 \mathrm{~cm}$ in length from the region close to the bifurcation). The samples were immersed in a phosphate-formaldehyde buffer for 24 hours at room temperature, and processed for routine histological techniques (dehydration, clearing, and inclusion in paraffin). Paraffin blocks were cut ( $0.5 \mu \mathrm{m}$ thick), stretched on glass slides, and placed in an oven, with subsequent staining in Hematoxylin-Eosin and fixation in $70 \%$ alcohol.

Histological sections were evaluated by optical microscopy (Olympus BX50, 400× magnification), and the uterine layers were measured by photomicrophads in photoesteriomicroscope (NSZ 606-T LED, 20× magnification) using Image J 1.44 program (Java 1.6.0-33; Wayne Rasband, National Institutes of Health, USA).

The total thickness of the uterine wall, endometrium, and myometrium was measured $(\mu \mathrm{m})$ in three different fields for each histological sample.

\subsection{Proteomics Analysis}

For proteomics analysis, samples from the distal region of the uterine horns $(0.5 \mathrm{~cm}$ of length) were immersed and 
stored in liquid nitrogen for later lyophilization (Liotop), protein dosing (Bradford method), and protein extraction (400 $\mu \mathrm{L})$ by two-dimensional agarose gel electrophoresis (2D).

Each sample was added with a rehydration solution $(7 \mathrm{M}$ urea, $2 \mathrm{M}$ thiourea, $65 \mathrm{mM}$ dithiothreitol, $0.5 \%$ free ampholytes, $0.5 \%$ CHAPS, and bromophenol blue), satisfactory for $250 \mu \mathrm{L}$. This solution was added to the hydration tray channels and incubated with $13 \mathrm{~cm}$ strips with a linear immobilized pH gradient of 3-10 (IPGs; GE Lifesciences, USA) for 18 hours.

The isoelectric focusing was performed on an ETTAN TM IPGphorII TM equipment (GE Lifesciences), with the following programming: $100 \mathrm{~V}, 250 \mathrm{~V}, 500 \mathrm{~V}, 8000 \mathrm{~V}(12750$ Volts hour $(\mathrm{Vh})$ and $8000 \mathrm{~V}(40000 \mathrm{Vh})$. The strips were kept for 15 minutes under gentle agitation in equilibrium buffer I ( $6 \mathrm{M}$ urea, $50 \mathrm{mM}$ Tris- $\mathrm{HCl} \mathrm{pH}$ 8.8, 29.3\% glycerol, $2 \%$ SDS, $1 \%$ dithiothreitol) and rebalanced for another 15 minutes in another substance similar to equilibrium buffer I, however, containing $2.5 \%$ iodoacetamide instead of dithiothreitol.

Afterward, the proteins were separated on 15\% SDS-PAGE polyacrylamide gel (SE 600 Ruby - Amersham Biosciences, USA) with a current of $25 \mathrm{~mA}$ per gel and a maximum voltage of $500 \mathrm{~V}$ (Hoefer SE 600; GE LifeSciences). A molecular marker with the following molecular weights was added: $12 \mathrm{kDa}, 17 \mathrm{kDa}, 24 \mathrm{kDa}, 31 \mathrm{kDa}, 38 \mathrm{kDa}, 52 \mathrm{kDa}, 76 \mathrm{kDa}$, $102 \mathrm{kDa}, 150 \mathrm{kDa}$, and $225 \mathrm{kDa}$ (Amersham ECL Rainbow Molecular Weight Markers; GE LifeSciences, USA). The proteins were visualized using the colloidal Coomassie method and scanned for analysis by the PDquest software.

\subsection{Statistical analysis}

Data of uterine measurements and number of spots were analyzed using a one-way ANOVA and compared with the Student't-test between the stages. A P value $<0.05$ was considered for statistical significance.

\section{Results}

In all phases of the normal estrous cycle, the endometrium presented irregular longitudinal folds, with the surface covered by a cubic or simple cylindrical epithelium, and a lamina propria of connective tissue and the endometrial glands (EG) were of the simple tubular type constituted by simple cubic epithelium or low cylindrical.

In the proliferative phases of proestrus (Figure 1A) and estrus (Figure 1B) in the histomorphometric analysis, the EG presented rectilinear morphology with a narrow flame and a slight depth in the endometrial tissue. In the secretory phase of diestrus (Figure 1C), these EG increased in density and size, presenting a tortuous morphology with dilation of the flame to accommodate the endometrial secretion.

In the anestrus (Figure 1D), both endometrial and EG extracts were reduced. In the myometrium, two thick smooth muscle layers were observed - circular internal and external longitudinal - in all phases. However, the vascular extract showed large diameter vessels in the proestrus (Figure 1A) and estrus (Figure 1B), and of smaller caliber in the diestrus (Figure 1C) and anestrus (Figure 1D). In turn, the perimetry was visualized by covering the uterine wall externally with loose connective tissue. 
Figure 1 - Histological analysis and respective illustration of protein extraction in a 2D electrophoresis master gel from the uterus of 18 healthy bitches in different stages of the estrous cycle: proestrus $(\mathrm{A}, n=5)$, estrus $(\mathrm{B}, n=5)$, diestrus $(\mathrm{C}, n=5)$, and anestrus (D, $n=3)$. In the histomorphometry analysis, different thicknesses of the endometrium (End), myometrium (Myo), and perimeter (Per) are observed during the phases of the estrous cycle. In the proteomic analysis, a greater number of spots was observed in the estrus (B), showing that this is the phase of greater protein synthesis by the uterus.

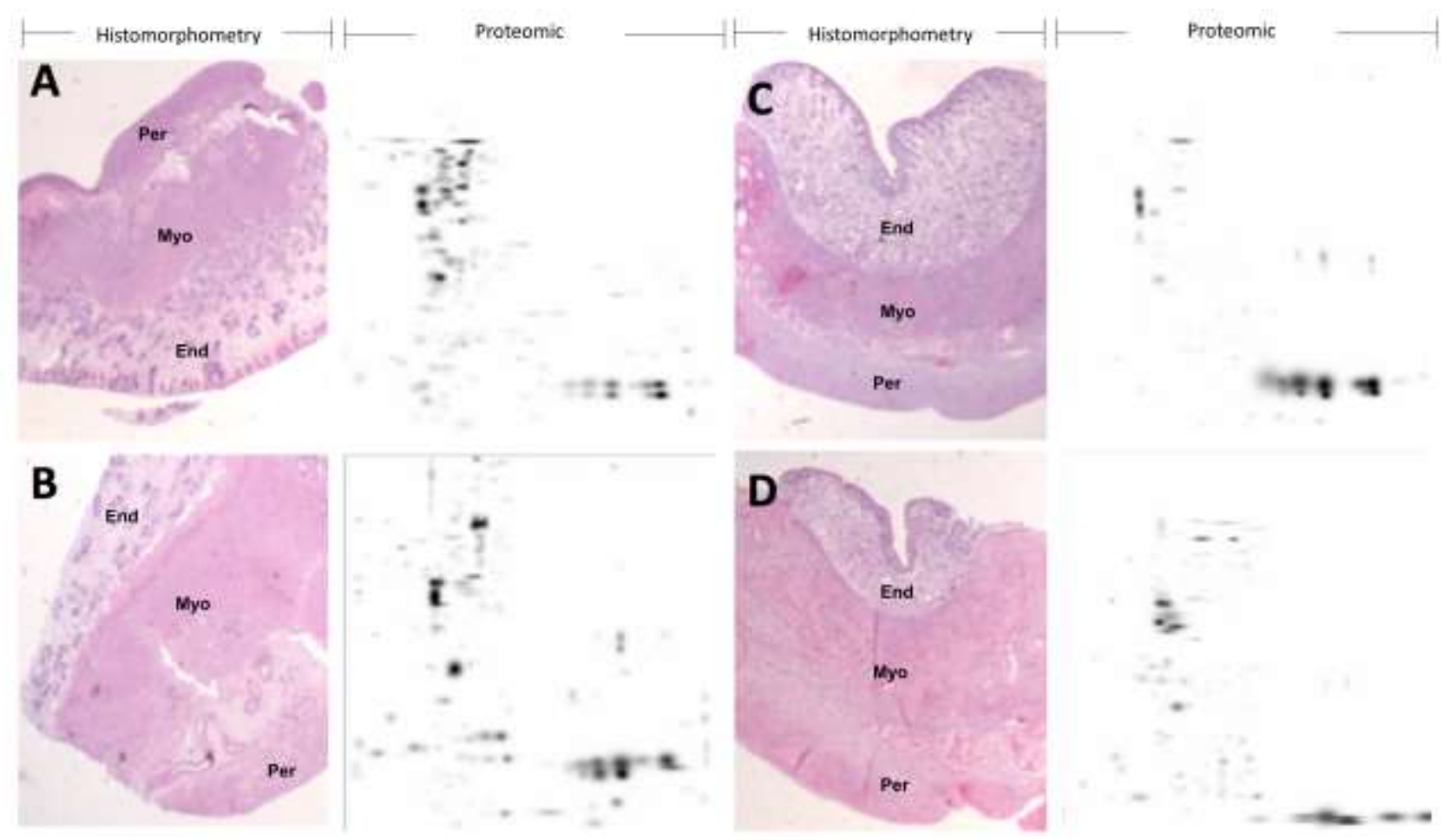

Source: Authors

In the proteomic analysis, the canine uterus presented a protein profile of goo reproducibility per phase (range of pI: 3.5-9.0; PM: 24-150 KDa), with possible isoforms. During estrus, the largest number of spots was identified, followed by proestrus, diestrus, and anestrus (Table 1), and eleven spots were present in all phases evaluated. The number of sports in each estrous cycle is shown in Figure 1.

Table 1 - Histomorphometric and proteomic analysis of the uterus of healthy female dogs during the different stages of the estrous cycle.

\begin{tabular}{|c|c|c|c|c|}
\hline \multirow{2}{*}{$\begin{array}{l}\text { Stages of the } \\
\text { estrous cycle }\end{array}$} & \multicolumn{3}{|c|}{ Histomorphometry } & \multirow{2}{*}{$\begin{array}{c}\text { Proteomic } \\
\text { No. of spots } \\
\text { by stage }\end{array}$} \\
\hline & $\begin{array}{l}\text { Uterine wall } \\
\qquad(\mu \mathrm{m})\end{array}$ & $\begin{array}{c}\text { Endometrium } \\
(\mu \mathrm{m})\end{array}$ & $\begin{array}{c}\text { Myometrium } \\
(\mu \mathrm{m})\end{array}$ & \\
\hline Proestrus & $854.0 \pm 55.9^{c}$ & $265.3 \pm 45.2^{\mathrm{c}}$ & $559.98 \pm 51.4^{\mathrm{b}}$ & $185 \pm 21^{\mathrm{b}}$ \\
\hline Estrus & $1145.2 \pm 211.1^{\mathrm{b}}$ & $473.4 \pm 68.7^{\mathrm{b}}$ & $662 \pm 69.8^{\mathrm{b}}$ & $253 \pm 45^{\mathrm{a}}$ \\
\hline Diestrus & $2223.8 \pm 229.8^{\mathrm{a}}$ & $819.7 \pm 109.1^{\mathrm{a}}$ & $1392.6 \pm 294.2^{\mathrm{a}}$ & $113 \pm 39^{c}$ \\
\hline Anestrus & $675.9 \pm 43 .^{\mathrm{d}}$ & $128.3 \pm 31.3^{\mathrm{d}}$ & $539 \pm 84.5^{\mathrm{b}}$ & $80 \pm 21^{\mathrm{d}}$ \\
\hline
\end{tabular}

Data were obtained from the Image $\mathrm{J}$ software. Values were expressed as mean \pm SD. Different letter indicate statistical difference $(p<0.05)$ between the lines in the same column $\left({ }^{a, b, c, d}\right)$.

Source: Authors. 


\section{Discussion}

Although histology is a widespread and accessible technique, the few uterine histomorphometric studies in bitches have addressed the phases of metestrus and anestrus (Galabova et al., 2003) or hormonal treatment conditions (Salinas, Miglino, \& Del Sol, 2017), as well as in females submitted to elective castration (Monteiro et al., 2012; Camargo et al., 2019). Uterine changes are influenced by estrogen and progesterone (Holst, 2019; Vermeirsch et al., 2000), and we demonstrated the histomorphometry of all phases for the first time in the canine species.

The thickness of the uterine wall and endometrium was reduced in the anestrus, however, they increased significantly and in increasing order from the proestrus, estrus to the diestrus, with myometrium also thick in this phase (Table 1). This change resulted from the growth of the mucosa, the accumulation of secretion and edema in the stroma, which occur in the diestrus (Holst, 2019).

In the proteomic study, the largest number of spots during estrus in our findings (Table 1) corresponded to the high mucus synthesis by EG, which is rich in mucin, ions, water, enzymes, peptides, antimicrobial compounds, and immunoglobulins (Agostinis et al., 2019), allowing the transit of sperm and protecting the uterus of ascending infections.

Despite the diestrus phase showed a significant increase in the uterine wall, morphological changes in the EG of endometrium and myometrium with increased diameter and size, and tortuous appearance, we observed that it was in the estrus that the greatest number of identified proteins occurred. This finding is possibly related to the participation of these proteins in preparing the uterus for the reception of gametes during fertilization. However, in bovine (Faulkner et al., 2013) and swine (Lee et al., 2013) species, the secretory or diestrus phase, under the action of progesterone, is reported as the phase with the highest number of proteins, differently from the canine species.

Although molecular dynamics studies are known in equine (Swegen et al., 2017), bovine (Faulkner et al., 2013), and swine (Lee et al., 2013), few studies have addressed the phases of the canine estrous cycle. It is essential to understand the proteomic profile in the proliferative phases, in which the uterus is adapted to receive sperm and, during the secretory phase, to receive the embryo. Because uterine proteomic studies in female dogs are restricted to the diestrus during the implantation period (Praderio et al., 2019), estrus (Fahiminiya et al., 2010), or proestrus (Reynaud et al., 2015), our study becomes be innovative and promising because it presents all phases of the estrous cycle.

\section{Conclusion}

In conclusion, we showed uterine histomorphometric and proteomic changes in all phases of the estrous cycle of healthy bitches, with greater thickness in uterine structures in diestrus, but greater number of spots in estrus, probably due to uterine preparation by proteins in estrus for fertilization. These findings are promising for prospects the identification of proteins responsible for biological processes during the estrous cycle. In this sense, studies using mass spectrometry can qualitatively identify the predominant protein groups in each phase of the cycle.

\section{References}

Agostinis, C., Mangogna, A., Bossi, F., Ricci, G., Kishore, U. \& Bulla, R. (2019). Uterine Immunity and Microbiota: A Shifting Paradigm. Frontiers in Immunology, 10(2387), 1-11.

Aplin, J. D., Fazleabas, A. T., Glasser, S. R. \& Giudice, L. C. (2008). The Endometrium: Molecular, Cellular and Clinical Perspectives (2nd ed.). Boca Raton: CRC Press.

Camargo, K. S., Aleixo, G. A. S., Penaforte Júnior, M. A., Galeas, G. R., Trajano, S. C., Melo, K. D., Ferreira, M. S. S., Andrade, L. S. S. \& Lopes, L. A. (2019). Achados histopatológicos em úteros e ovários de cadelas submetidas à castração eletiva pelas técnicas de ovariectomia ou ovariohisterectomia. Medicina Veterinária (UFRPE), 13(4), 577-582.

Fahiminiya, S., Reynaud, K., Labas, V., Batard, S., Chastant-Maillard, S. \& Gérard, N. (2010). Steroid hormones content and proteomic analysis of canine follicular fluid during the preovulatory period. Reproductive Biology and Endocrinology, 8 (132), 1-13. 
Research, Society and Development, v. 10, n. 11. e18101119093, 2021

(CC BY 4.0) | ISSN 2525-3409 | DOI: http://dx.doi.org/10.33448/rsd-v10i11.19093

Faulkner, S., Elia, G., O' Boyle, P., Dunn, M. \& Morris, D. (2013). Composition of the bovine uterine proteome is associated with stage of cycle and concentration of systemic progesterone. Proteomics, 13(22), 3333-3353.

Freitas, L. A., Villamil, P. R., Moura, A. A. A. N., Silva, \& L. D. M. (2015). Proteoma uterino durante o ciclo reprodutivo e gestação em animais domésticos. Revista Brasileira de Reprodução Animal, 39(4), 375-381.

Galabova, G., Egerbacher, M., Aurich, J. E., Leitner, M. \& Walter, I. (2003). Morphological changes of the endometrial epithelium in the bitch during metoestrus and anoestrus. Reproduction in Domestic Animals, 38(5), 415-420.

Gao, H., Wu, G., Spencer, T. E., Johnson, G. A. \& Bazer, F. W. (2009). Select nutrients in the ovine uterine lumen. II. Glucose transporters in the uterus and peri-implantation conceptuses. Biology of Reproduction, 80(1), 94-104.

Holst, P. (2019). Canine Reproduction: The Breeder's Guide (3rd ed.). Dogwise Publishing.

Kuleš, J., Horvatić, A., Guillemin, N., Ferreira, R. F., Mischke, R., Mrljak, V., Chadwick, C. C. \& David Eckersall, P. (2020). The plasma proteome and the acute phase protein response in canine pyometra. Journal of Proteomics, 223, 103817.

Lee, W. Y., Chai, S. Y., Lee, K. H., Park, H. J., Kim, J. H., Kim, B., Kim, N. H., Jeon, H. S., Kim, I. C., Choi, H. S. \& Song, H. (2013). Identification of the DDAH2 protein in pig reproductive tract mucus: a putative oestrus detection marker. Reproduction in Domestic Animals, 48(1), 13-16.

Monteiro, C. M. R., Perri, S. H. V., Carvalho, R. G., da Silva, A. M. \& Koivisto, M. B. (2012). Histomorfometria do corno uterino de gatas (Felis catus) submetidas à ovariosalpingohisterectomia. Brazilian Journal of Veterinary Research and Animal, 49(3), 225-231.

Pereira A. S., Shitsuka, D. M., Parreira, F. J. \& Sitsuka, R. (2018). Metodologia da pesquisa científica. UFSM.

Praderio, R. G., García Mitacek, M. C., Núñez Favre, R., Rearte, R., De La Sota, R. L. \& Stornelli, M. A. (2019). Uterine endometrial cytology, biopsy, bacteriology, and serum C-reactive protein in clinically healthy diestrus bitches. Theriogenology, 131, 153-161.

Ramos, J. L. G., Ramos, C. L. F. G., Cunha, I. C. N., Carvalho, E. C. Q., Shimoda, E. \& Luz, M. R. (2015). Análise histomorfométrica do útero na espécie canina do nascimento aos seis meses de idade. Arquivo Brasileiro de Medicina Veterinária e Zootecnia, 67(1), 41-48.

Reynaud, K., Saint-Dizier, M., Tahir, M. Z., Havard, T., Harichaux, G., Labas, V., Thoumire, S., Fontbonne, A., Grimard, B. \& Chastant-Maillard, S. (2015). Progesterone plays a critical role in canine oocyte maturation and fertilization. Biology of Reproduction, 93(4), 87.

Salinas, P., Miglino, M. A. \& Del Sol, M. (2017). Histomorphometrics and quantitative unbiased stereology in canine uteri treated with medroxyprogesterone acetate. Theriogenology, 95, 105-112.

Swegen, A., Grupen, C. G., Gibb, Z., Baker, M. A., de Ruijter-Villani, M., Smith, N. D., Stout, T. A. E. \& Aitken, R. J. (2017). From Peptide Masses to Pregnancy Maintenance: A Comprehensive Proteomic Analysis of The Early Equine Embryo Secretome, Blastocoel Fluid, and Capsule. Proteomics, 17(1718), $1-30$.

Valdés, A., Holst, B. S., Lindersson, S. \& Ramström, M. (2019). Development of MS-based methods for identification and quantification of proteins altered during early pregnancy in dogs. Journal of Proteomics, 192, 223-232.

Vermeirsch, H., Simoens, P., Hellemans, A., Coryn, M. \& Lauwers, H. (2000). Immunohistochemical detection of progesterone receptors in the canine uterus and their relation to sex steroid hormone levels. Theriogenology, 53(3), 773-788. 